\title{
Antioxidant Evaluation of the Aqueous Extract of Hulls of Campsiandra laurifolia in Colitis Induced by Acetic Acid in Wistar Rats
}

\section{Avaliação antioxidante do extrato aquoso de cascas de Campsiandra laurifolia na colite induzida por ácido acético em ratos Wistar}

Lucas Petitemberte de Souza ${ }^{10}$ Henrique Sarubbi Fillmann ${ }^{2 \oplus}$ Sandielly Rebeca Benitez da Fonseca ${ }^{3 \odot}$ Marilda da Silva Brasil ${ }^{4}$ Norma Anair Possa Marroni ${ }^{5(-)}$ Alexandre de Barros Falcão Ferraz ${ }^{60}$

1 Universidade Luterana do Brasil, Canoas, RS, Brasil

Address for correspondence Dr. Alexandre de Barros Falcão Ferraz,

2 Pontifícia Universidade Católica do Rio Grande do Sul, Porto Alegre, RS, Brasil Avendia Farroupilha, 8001-São José, Canoas - RS, 92425-020, Brasil

3 Programa de Pós-Graduação em Ciências Médicas; Universidade (e-mail: alexandre.ferraz@ulbra.br).

Federal do Rio Grande do Sul, Porto Alegre, RS, Brasil

4 Programa de Pós-Graduação em Ciências Biológicas: Fisiologia;

Universidade Federal do Rio Grande do Sul, Porto Alegre, RS, Brasil

${ }^{5}$ Departamento de Fisiologia; Universidade Federal do Rio Grande do

Sul, Porto Alegre, RS, Brasil

${ }^{6}$ Laboratory of Phytochemistry, Universidade Luterana do Brasil,

Canoas, RS, Brasil

J Coloproctol 2021;41(2):138-144.
Abstract
Keywords
- antioxidant
- tannins
- oxidative stress
- colitis

Due to the ethnopharmacological use of Campsiandra laurifolia (Fabaceae), popularly known as Acapurana, to treat wounds and ulcers, associated with the lack of alternative treatments for intestinal inflammations such as ulcerative colitis (UC), the present work sought to characterize its phytochemical and antioxidant activities, and to evaluate remedial action in experimental colitis with acetic acid. Phytochemical analyzes were performed through qualitative and quantitative colorimetric tests of the main secondary metabolites. In the colitis model, 24 male Wistar rats aged \pm 60 days old were used, divided into 4 groups: Control (CO) control + aqueous extract of C. laurifolia $50 \mathrm{mg} / \mathrm{kg}(\mathrm{CO}+\mathrm{A} 50)$; Colitis (CL); and Colitis + aqueous extract of C. laurifolia $50 \mathrm{mg} / \mathrm{kg}(\mathrm{CL}+\mathrm{A} 50)$. Measurement of sphincter anal pressure and histological tests of the large intestine, lipoperoxidation (LPO), enzyme activity of superoxide dismutase (SOD), and levels of glutathione (GSH) were performed. For statistical analysis, the oxidative stress (OS) results were expressed as means \pm standard error, adopting a significance level of $p<0.05$. The screening indicated the presence of flavonoids, saponins and tannins in the extract, with high levels of phenolic received

May 22, 2020

accepted

January 15, 2021
DOI https://doi.org/

10.1055/s-0041-1730258.

ISSN 2237-9363.

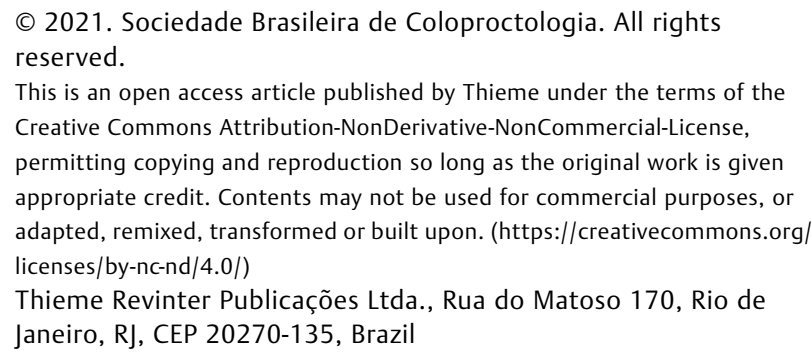

(c) 2021. Sociedade Brasileira de Coloproctologia. All rights reserved.

This is an open access article published by Thieme under the terms of the Creative Commons Attribution-NonDerivative-NonCommercial-License, permitting copying and reproduction so long as the original work is given appropriate credit. Contents may not be used for commercial purposes, or adapted, remixed, transformed or built upon. (https://creativecommons.org/ licenses/by-nc-nd/4.0/)

Thieme Revinter Publicações Ltda., Rua do Matoso 170, Rio de Janeiro, RJ, CEP 20270-135, Brazil 


\section{Resumo}

\section{Palavras-chave \\ - antioxidante \\ - taninos \\ - estresse oxidativo \\ - colite}

compounds and tannins, and was related to high antioxidant capacity. In the histological analysis, the $\mathrm{CL}$ group presented loss of the crypts, edema and inflammatory infiltrate. The use of $C$. laurifolia extract restructured the crypts, decreased edema and increased sphincter anal pressure, with a decrease in LPO, SOD, and an increase in GSH. It is suggested that the use of $C$. laurifolia extract reduces $O S$ due to its antioxidant power conferred by the phenolic compounds present in the extract.

Devido ao uso etnofarmacológico de Campsiandra laurifolia (Fabaceae), popularmente conhecida como Acapurana, para tratar feridas e úlceras, associado à falta de alternativas de tratamentos para as inflamações intestinais como a retocolite ulcerativa (RCU), o presente trabalho buscou caracterizar sua constituição fitoquímica, sua atividade antioxidante, e avaliar sua ação reparadora na colite experimental com ácido acético. As análises fitoquímicas foram realizadas por meio de ensaios colorimétricos qualitativos e quantitativos dos principais metabólitos secundários. No modelo de colite, foram utilizados 24 ratos machos Wistar de \pm 60 dias de idade, divididos em 4 grupos: Controle (CO), controle + extrato aquoso de C. laurifolia $50 \mathrm{mg} / \mathrm{kg}$ (CO + A50); Colite (CL); e Colite + extrato aquoso de C. laurifolia $(C L+A 50)$. Foram realizadas aferições da pressão anal esfincteriana e avaliações histológicas do intestino grosso, lipoperoxidação (LPO), atividade da enzima superóxido dismutase (SOD) e níveis da glutationa (GSH). Para a análise estatística, resultados do estresse oxidativo (EO) foram expressos em médias \pm erro padrão, adotando um nível de significância de $p<0,05$. O screening indicou no extrato a presença de flavonoides, saponinas e taninos com altos teores de compostos fenólicos e taninos, relacionando-os a uma elevada capacidade antioxidante. $\mathrm{Na}$ análise histológica, o grupo $\mathrm{CL}$ apresentou perda das criptas, do edema e do infiltrado inflamatório. $O$ uso do extrato de $C$. laurifolia reestruturou as criptas, diminuiu o edema e aumentou a pressão anal esfincteriana, com diminuição da LPO, da SOD, e aumento da GSH. Sugere-se que o uso do extrato de C. laurifolia diminui o EO por seu poder antioxidante, conferido pelos compostos fenólicos presentes no extrato.

\section{Introduction}

Ulcerative rectocolitis (UC) is characterized as an inflammatory bowel disease (IBD), considered a serious public health problem, as it is chronic, recurrent, and affects young people in an economically productive phase, causing loss of quality of life. Symptoms are manifested by recurrent bloody diarrhea, followed by tenesmus and severe abdominal cramps. Treatment of the disease with aminosalicylates and corticosteroids leads to drug resistance and dependence. There is no confirmed etiology of IBD; however parasitic and bacterial agents are discarded, since there is no evidence of these. Associated with environmental, immunological, and genetic factors, the inflammatory action of UC increases the presence of free radicals (FR), as observed in animals submitted to experimental colitis, with an elevation of nitric oxide (NO) interacting in the anal musculature of the sphincter and decreasing its pressure. ${ }^{1-4}$

The experimental model of acetic acid-induced colitis (AA) is similar to human inflammatory diseases and also causes an increase in reactive oxygen species, which triggers an imbalance in the redox reactions of the cells with the highest FR production. Therefore, the antioxidant defense of cells becomes overloaded and generates oxidative stress (OS), which causes lipoperoxidation (LPO), leading to cell death. To fight this toxic process, the antioxidant system has enzymes, such as superoxide dismutase (SOD), that convert $\mathrm{O}_{2}$ into hydrogen peroxide, as well as nonenzymatic substances, such as glutathione (GSH) and phenolic compounds. ${ }^{4,5}$

Campsiandra laurifolia (Fabaceae) is a tree found in Brazil, more precisely in the states of Amapá, Amazonas, and Pará, popularly known as 'Acapurana'. In traditional medicine, $C$. laurifolia is recommended by quilombola communities to treat wounds, ulcers, etc. Besides, it stands out due to its immunosuppressive potential. Due to these facts, the objective of the present work was to characterize phytochemically the aqueous extract of hulls of $C$. laurifolia, as well as to evaluate its antioxidant potential in vitro, against 2,2diphenyl-1-picryl-hydrazil (DPPH), and in vivo in the AAinduced colitis model. ${ }^{6}$

\section{Methodology}

\section{Plant Material}

The hulls of C. laurifolia were collected in Manaus, in the state of Amazonas, Brazil, in April 2015. Access to Brazilian biodiversity was registered in the Sistema Nacional de 
Gerenciamento do Patrimônio Genético e Conhecimento Tradicional Associado (National System for the Management of Genetic Heritage and Associated Traditional Knowledge), under the AB614C4 protocol.

\section{Preparation of the Crude Aqueous Extract}

To obtain the crude extract, the hulls of $C$. laurifolia were dried and subjected to the method of extraction by decoction for 15 minutes. For this process, a 1:10 plant/solvent ratio was used. It was filtered, frozen, and subjected to lyophilization to obtain the crude aqueous extract.

\section{Phytochemical Analysis}

The extract of $C$. laurifolia was qualitatively and colorimetrically analyzed for the presence of alkaloids, coumarins, flavonoids, quinones, saponins, and tannins. The content of phenolic compounds and total tannins was assessed using the Folin-Ciocalteu test. The values were expressed in milligrams of gallic acid equivalent (GAE) per gram of extract. The total flavonoid content of the aqueous extract of $C$. laurifolia was quantified, using aluminum chloride as a chromogenic agent, and the result was expressed in milligrams of quercetin equivalent $(\mathrm{QE})$ per gram of extract. ${ }^{7-10}$

\section{Antioxidant Activity of DPPH}

For the antioxidant evaluation, the DPPH stable free radical was used. Methanol was used as blank; DPPH/methanol as a negative control; and quercetin as a positive control sample. ${ }^{11}$ After 30 minutes, absorbance was measured at $518 \mathrm{~nm}$ using a spectrophotometer model Biospectro SP-22 Shimadzu - UV-1602PC (Kyoto, Japan). The analyzes were performed in concentrations of $10,15,20,30$, and 40 $\mu \mathrm{g} / \mathrm{ml}$, and the antioxidant activity was expressed by the $\mathrm{IC}_{50} \mu \mathrm{g} / \mathrm{ml}$, calculated according to the following formula:

\footnotetext{
$\%$ DPPH inhibition $=[($ Abs + control - Abs sample $) \times 100] /$ Abs + control
}

\section{Animals and Procedures}

The procedures with the animals were in accordance with the recommendations of the Comissão de Pesquisa e Ética em Saúde do Grupo de Pesquisa e Pós-Graduação do Hospital das Clínicas de Porto Alegre (HCPA, in the Portuguese acronym) (Health Research and Ethics Committee of the Porto Alegre Clinical Hospital Research and Graduate Group), and with the guidelines of the Agência União Europeia da Experimentação Animal (European Animal Research Association). ${ }^{12}$ The experiment below was approved by the HCPA under the number 2019/ 0196.15.

Twenty-four male Wistar rats, $\sim 60$ day-old and $350 \mathrm{~g}$ of weight from the Laboratory of Animal Reproduction and Experimentation Center (CREAL, in the Portuguese acronym)) of the Universidade Federal do Rio Grande do Sul (UFRGS, in the Portuguese acronym) were used in a 12-hour light/dark cycle, temperature of $22+1-2^{\circ} \mathrm{C}$, relative humidity of between 40 and $60 \%$, air exhaustion, with water and food ad libitum. The animals were separated into four groups: $\mathrm{CO},(n=6)$ submitted to enema and simulation of oral treatment by gavage, with a saline solution; $\mathrm{CO}+\mathrm{A} 50,(n=6)$ enema with a saline solution, and administration of $50 \mathrm{mg} / \mathrm{kg}$ of aqueous extract of C. laurifolia during treatment; $\mathrm{CL},(n=6)$, colitis induction with AA and simulation of oral treatment by gavage with saline solution; and $\mathrm{CL}+\mathrm{A} 50,(n=6)$ colitis induction, plus administration of $50 \mathrm{mg} / \mathrm{kg}$ of aqueous extract of $C$. laurifolia during treatment. The model for colitis induction was an adaptation by Yamada et al. The animals were anesthetized with isoflurane, diluted in $100 \%$ of $\mathrm{O}_{2}$, and at a flow rate of $0.5 \mathrm{l} / \mathrm{min}$. Afterwards, the animals were submitted to intracolonic administration by an enema with $4 \mathrm{ml}$ of $4 \%$ AA solution. The $\mathrm{CO}$ and $\mathrm{CO}+\mathrm{A} 50$ groups received $4 \mathrm{ml}$ of $0.9 \%$ saline solution. The first treatment dose was administered 24 hours after colitis induction, once a day in the morning, orally, for 2 days, using water to dilute $50 \mathrm{mg} / \mathrm{kg}$ of aqueous extract of $C$. laurifolia in a total volume of $0.5 \mathrm{ml}$. After the treatment, the animals were anesthetized and sphincter anal pressure measurements were performed, followed by a medium ventral laparotomy, when the 8 -cm distal portion of the large intestine of the animals was removed. Part of the colon was preserved in $10 \%$ formaldehyde for subsequent histological analysis, and the rest was frozen at $-80^{\circ} \mathrm{C}$ for further analysis of oxidative stress (OE). At the end of the experiment, the animals were euthanized by exsanguination under deep anesthesia. ${ }^{13}$

\section{Sphincter anal Pressure}

After induction and treatment, the animals were anesthetized to assess sphincter anal pressure. An anorectal manometer (Proctossystem Viotti, São Paulo, SP, Brasil) was used. A balloon catheter was inserted into the anal canal and was pulled to record sphincter anal pressure. Three subsequent measurements were taken, and the measurement was expressed in $\mathrm{cm} / \mathrm{H}_{2} \mathrm{O}$. $^{4}$

\section{Histological Analyses}

For the histological analyses, part of the large intestine was packed in $10 \%$ buffered formaldehyde, and then were inserted in paraffin blocks that were subsequently cut in a rotating microtome in 3- $\mu \mathrm{m}$-thick slices, and were stained with hematoxylin and eosin. The slides were evaluated using a Nikon Labophot (Nikon, Tokyo, Japan) binocular microscope, at 100x magnification, by a researcher blinded to the treatments.

\section{In vivo Antioxidant Assessments}

To perform the techniques referring to LPO and to SOD and GSH activity, a large intestine homogenate was performed according to Llesuy et al. using $5 \mathrm{ml}$ of phosphate buffer solution ( $\mathrm{KCl} 1.15 \%$ per gram of bowel and phenylmethylsulfonyl fluoride, at a concentration of $100 \mathrm{mM}$ in isopropanol; $10 \mu \mathrm{l} / \mathrm{ml}$ per $\mathrm{ml}$ of added $\mathrm{KCl}$ ). The tissue was homogenized in Ultra-Turrax (IKA Werke, Staufen, BadenWürttemberg, Germany) on ice and centrifuged for 10 minutes at $3000 \mathrm{rpm}$ in a refrigerated centrifuge at $4^{\circ} \mathrm{C}$. The supernatant was pipetted in $1.5 \mathrm{ml}$ tubes, the precipitate was discarded, and, at the end, the samples were kept in a freezer to perform the techniques. Protein quantification was performed using the Bradford method, according to Hartmann et al., with a standard solution of bovine albumin, in a 
concentration of $1 \mathrm{mg} / \mathrm{ml}$. The samples were measured in a spectrophotometer at $625 \mathrm{~nm}$, with values expressed in $\mathrm{mg} / \mathrm{ml}^{14,15}$

\section{Lipoperoxidation}

The LPO was based on the technique of thiobarbituric acid reactive substances (TBARS), by Buege et al., in which the amount of aldehydes generated by lipid peroxidation is estimated according to Hartmann et al. The final product was read in spectrophotometry with a 535-nm wavelength. The concentration obtained was expressed in $\mathrm{nmol} / \mathrm{mg}$ prot. The appearance of staining occurred due to the presence of malondialdehyde, in addition to other substances from LPO in biological material. ${ }^{16}$

\section{Superoxide Dismutase and Glutathione Activity}

The SOD activity was defined according to the protocol by Misra et al., based on the inhibition of the reaction of the superoxide radical using adrenaline, which turns into adrenochrome when in an alkaline medium, and is detected through spectrophotometry, with a reading at $480 \mathrm{~nm}$, with values expressed in USOD/mg prot. ${ }^{17}$ For the levels of GSH, a homogenate was performed, following the method of Beutler et al., detected through spectrophotometry, with a reading at $412 \mathrm{~nm}$. The activity was expressed in $\mu \mathrm{mol} / \mathrm{mg}$ prot. $^{18}$

\section{Statistical Analysis}

All quantitative data are presented as means \pm standard error. GraphPad Prism 8 (GraphPad, San Diego, CA, USA) was used for the characterization of $C$. laurifolia and its antioxidant potential in vitro, and the Student $t$-test was used for the quantitative analysis of secondary metabolites.

In vivo antioxidant activity data were presented with statistical significance, adopting a significance level of $p<0.05$. The calculation was performed in GraphPad Instant version 3.0 for Windows (GraphPad, San Diego, CA, USA), and we used one-way analysis of variance (ANOVA), followed by the Student-Newman-Keuls test for parametric data.

\section{Results}

\section{Phytochemical Characterization and Antioxidant Potential in vitro}

In the aqueous extract of hulls of $C$. laurifolia, flavonoids, tannins, and saponins were found. In the assays, it was possible to determine the contents of the phenolic compounds: $670.64 \pm 7.94 \mathrm{mg} / \mathrm{g}$ GAE; total tannins: $476.78 \pm 23.44 \mathrm{mg} / \mathrm{g}$ GAE; total flavonoids: $1.16 \pm 0.03 \mathrm{mg} / \mathrm{g}$ QE. As for DPPH, the antioxidant potential of the sample $\mathrm{IC}_{50}=16.51 \pm 0.65 \mu \mathrm{g} / \mathrm{ml}$ was observed, which was higher than that of quercetin, positive control, $\mathrm{IC}_{50}=18.22 \pm 2.22 \mu \mathrm{g} / \mathrm{ml}$.

\section{Histological Evaluation}

In the photomicrographic analysis of the distal portion of the large intestine, it was possible to observe in the $\mathrm{CO}$ and $\mathrm{CO}+\mathrm{A} 50$ groups the integrity in the architecture of the intestine (-Fig. 1A and 1B). When analyzing the photomicrographs in the CL group, destruction of the crypts, edema, hemorrhage in the submucosa and of the inflammatory infiltrate were seen ( $\mathbf{- F i g}$. 1C). In the photomicrograph in the $\mathrm{CL}+\mathrm{A} 50$ group, it was possible to observe crypts with

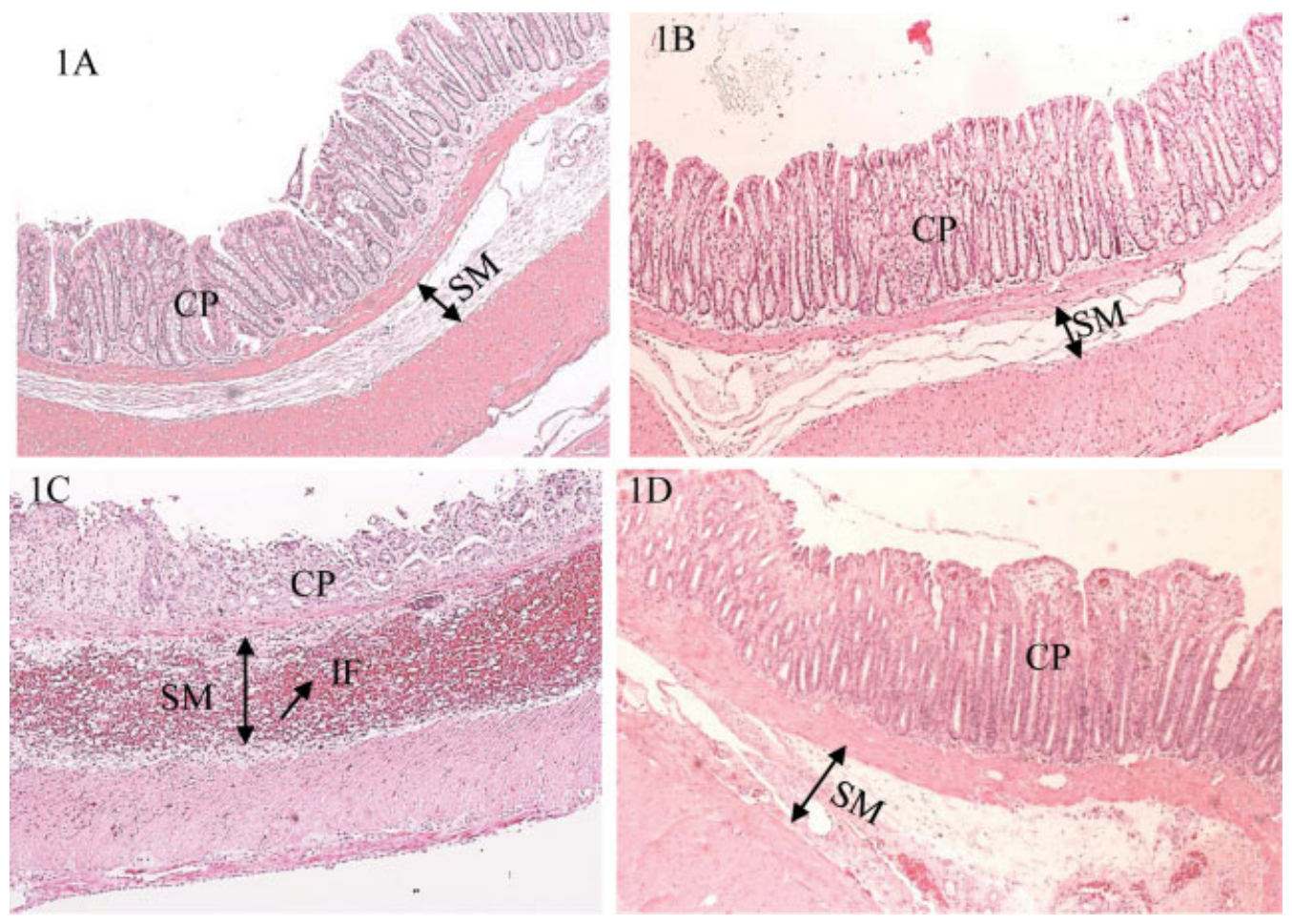

Fig. 1 Photomicrograph representing the histology by hematoxylin-eosin of the intestines of the rats in the control groups and treated with aqueous extract of $C$. laurifolia, at $100 x$ magnification. (A) $C O$ group. $C P=C r y p t s ; ~ S M=$ submucosa; (B) $C O+A 50$ group. $C P=C r y p t s$;

$\mathrm{SM}=$ submucosa; (C) CL Group. $\mathrm{CP}=$ Crypts; $\mathrm{SM}=$ submucosa; $\mathrm{IF}=$ Inflammatory Infiltrate; (D) $\mathrm{CL}+\mathrm{A} 50$ group. $\mathrm{CP}=\mathrm{Crypts}$; $\mathrm{SM}=\mathrm{Submucosa}$. 
greater integrity and a decrease in the inflammatory infiltrate and edema (- Fig. 1D).

\section{Sphincter anal Pressure}

A significant decrease in sphincter anal pressure was observed in the CL group when compared with the control groups. When administering the aqueous extract of $C$. laurifolia to animals with colitis, it was possible to see a significant increase in sphincter anal pressure in the $\mathrm{CL}+\mathrm{A} 50$ group when compared with the $\mathrm{CL}$ group (-Fig. 2), expressed in $\mathrm{cm} / \mathrm{H}_{2} \mathrm{O}$. $\mathrm{CO}=28.2 \pm 1.60 ; \mathrm{CO}+\mathrm{A} 50=28.0$ $\pm 1.83 ; \mathrm{CL}=15.1 \pm 0.97 ; \mathrm{CL}+\mathrm{A} 50=26.4 \pm 1.46$.

\section{Lipoperoxidation}

It was possible to observe a significant increase in the LPO of the $\mathrm{CL}$ group when compared with the control groups. In the $\mathrm{CL}+\mathrm{A} 50$ group treated with aqueous extract of $C$. laurifolia, a significant decrease in damage was noticed when compared with the CL group (-Fig. 3), which was expressed in $\mathrm{nmol} / \mathrm{mg}$ prot. $\mathrm{CO}: 0.318 \pm 0.02 ; \mathrm{CO}+\mathrm{A} 50: 0.310 \pm 0.14$; CL: $0.720 \pm 0.06 ; \mathrm{CL}+\mathrm{A} 50: 0.414 \pm 0.06$.

\section{Superoxide Dismutase and Glutathione Activities}

The SOD activity showed a significant increase in the $\mathrm{CL}$ group when compared with the control, as well as a significant reduction in the colitis group that was treated with the aqueous extract of $C$. laurifolia, $\mathrm{CL}+\mathrm{A} 50$, compared with the colitis group (-Fig. 4), expressed in USOD/mg prot. CO $=4.630 \pm 0.7707 ; \quad \mathrm{CO}+\mathrm{A} 50=6.884 \pm 0.6935 ; \mathrm{CL}=12.623$ $\pm 2.3978 ; \mathrm{CL}+\mathrm{A} 50=3.067 \pm 1.0406$.

The GSH levels in the CL group were significantly reduced when compared with the control groups. When analyzing the GSH levels in the $\mathrm{CL}+\mathrm{A} 50$ group - a colitis group treated with the aqueous extract of $C$. laurifolia - it was possible to observe a significant increase when comparing it with the $\mathrm{CL}$ group (-Fig. 5), expressed in $\mu \mathrm{mol} / \mathrm{mg}$ prot. CO: $0.0838 \pm 0.005 ; \quad \mathrm{CO}+\mathrm{A} 50: \quad 0.685 \pm 0.004 ; \quad \mathrm{CL}: \quad 0.0456 \pm$ $0.004 ; \mathrm{CL}+\mathrm{A} 50: 0.0685 \pm 0.001$.

\section{Sphincter Anal Pressure}

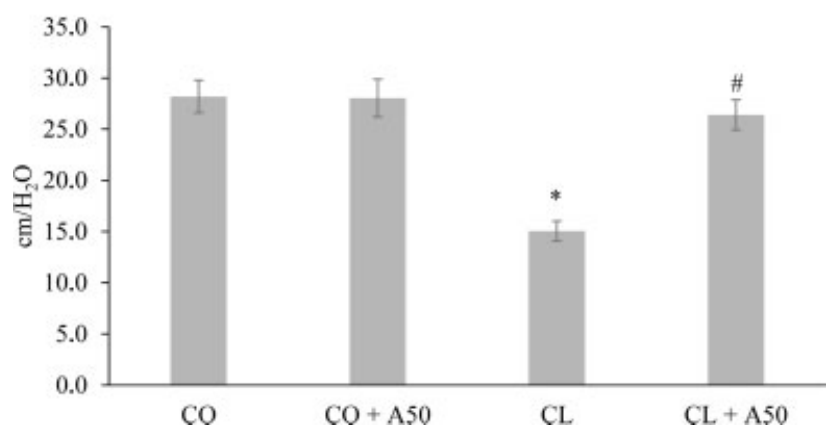

Fig. 2 Values of sphincter anal pressure, on average \pm standard error, obtained in the different groups, in $\mathrm{cm} / \mathrm{H}_{2} \mathrm{O}$. $\mathrm{CO}=28.2 \pm 1.60 ; \mathrm{CO}$ $+\mathrm{A} 50=28.0 \pm 1.83 ; \mathrm{CL}=15.1 \pm 0.97 ; \mathrm{CL}+\mathrm{A} 50=26.4 \pm 1.46$. *Significant difference, $p<0.001$ in the $C L$, in relation to the $C O$ and $\mathrm{CO}+\mathrm{A} 50$ groups; \#Significant difference, $p<0.001$ in $\mathrm{CL}+\mathrm{A} 50$ when compared with $\mathrm{CL}$. $\mathrm{CO}=$ control, $\mathrm{CO}+\mathrm{A} 50=$ control treated with $C$. laurifolia; $\mathrm{CL}=$ colitis; $\mathrm{CL}+\mathrm{A} 50=$ colitis treated with $\mathrm{C}$. Iaurifolia.

LPO

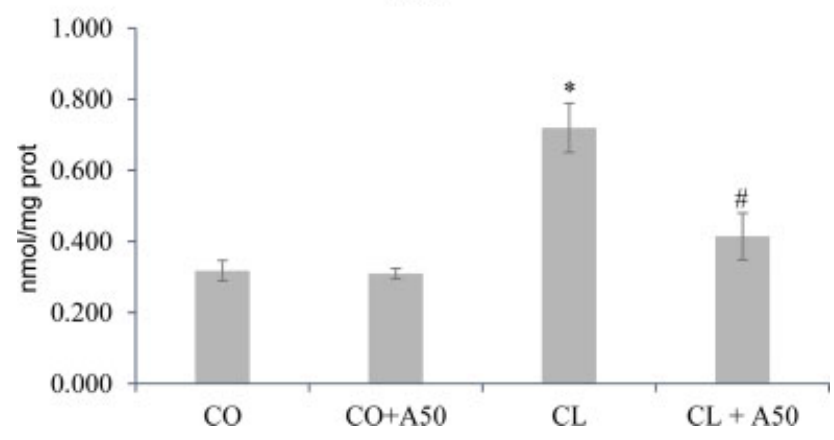

Fig. 3 LPO values, on average \pm standard error, obtained in the different groups analyzed, in $\mathrm{nmol} / \mathrm{mg}$ prot. $\mathrm{CO}: 0.318 \pm 0.02$; $\mathrm{CO}+\mathrm{A} 50: 0.310 \pm 0.14 ; \mathrm{CL}: 0.720 \pm 0.06 ; \mathrm{CL}+\mathrm{A} 50: 0.414 \pm 0.06$. *Significant difference $p<0.001$ in the $C L$, in relation to the $C O$ and $\mathrm{CO}+\mathrm{A} 50$ groups. \#Significant difference $p<0.01$ in $\mathrm{CL}+\mathrm{A} 50$ when compared with $\mathrm{CL}$. $\mathrm{CO}=$ control, $\mathrm{CO}+\mathrm{A} 50=$ control treated with $C$. laurifolia; $\mathrm{CL}=$ colitis; $\mathrm{CL}+\mathrm{A} 50=$ colitis treated with $\mathrm{C}$. laurifolia.

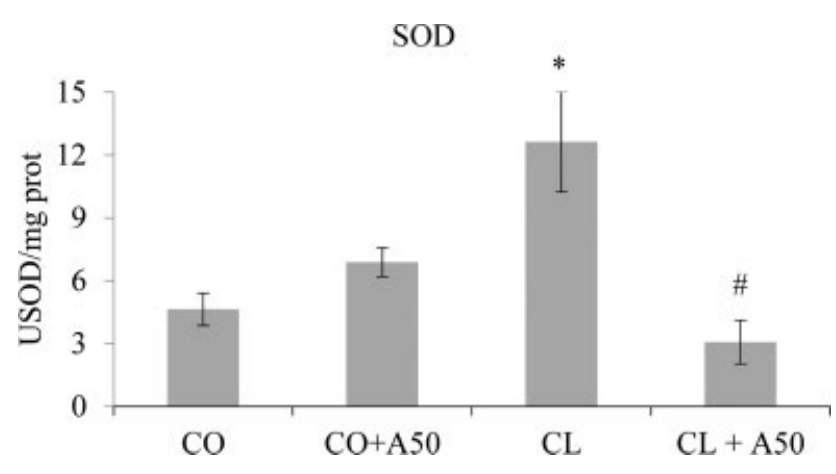

Fig. 4 SOD enzyme action values, on average \pm standard error, obtained in the different groups analyzed, in USOD/mg prot. CO $=4.630 \pm 0.7707 ; \mathrm{CO}+\mathrm{A} 50=6.884 \pm 0.6935 ; \mathrm{CL}=12.623 \pm 2.3978$; $\mathrm{CL}+\mathrm{A} 50=3.067 \pm 1.0406$. *Significant difference $p<0.01$ in the $\mathrm{CL}$, in relation to the $\mathrm{CO}=$ control. \#Significant difference $p<0.05$ in $\mathrm{CL}+\mathrm{A} 50$, compared with $\mathrm{CL}$. $\mathrm{CO}=$ control, $\mathrm{CO}+\mathrm{A} 50=$ control treated with $C$. laurifolia; $\mathrm{CL}=$ colitis; $\mathrm{CL}+\mathrm{A} 50=$ colitis treated with $C$. laurifolia.

GSH

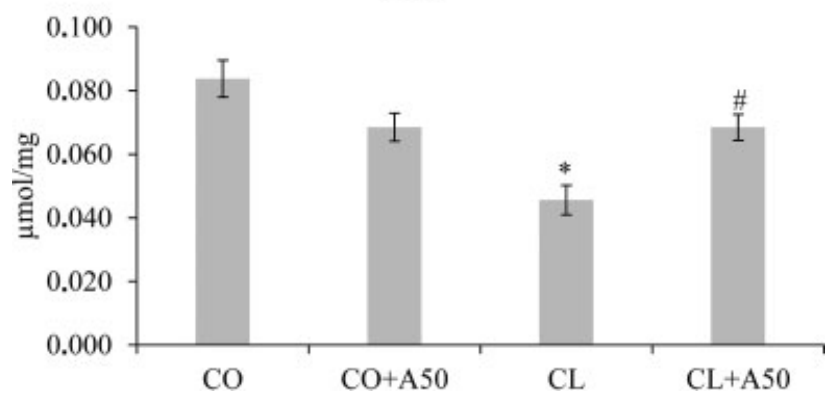

Fig. $5 \mathrm{GSH}$ level values, on average \pm standard error, obtained in the different groups analyzed, in $\mu \mathrm{mol} / \mathrm{mg}$ prot. $\mathrm{CO}: 0.0838 \pm 0.005$; $\mathrm{CO}+\mathrm{A} 50: 0.685 \pm 0.004 ; \mathrm{CL}: 0.0456 \pm 0.004 ; \mathrm{CL}+\mathrm{A} 50$ : $0.0685 \pm 0.001$. *Significant difference $p<0.05$ in $C L$, in relation to $\mathrm{CO}=$ control and $\mathrm{CO}+\mathrm{A} 50=$ control treated with $C$. laurifolia; \#Significant difference $p<0.05$ in $\mathrm{CL}+\mathrm{A} 50$ compared with $\mathrm{CL}$. $\mathrm{CO}=$ control, $\mathrm{CO}+\mathrm{A} 50=$ control treated with $C$. laurifolia; $\mathrm{CL}=$ colitis; $\mathrm{CL}+\mathrm{A} 50=$ colitis treated with $\mathrm{C}$. laurifolia. 


\section{Discussion}

The etiology of UC is being studied a lot and, therefore, new study models are proposed and used. In the present study, we used the AA-induced UC model to cause injury to the intestines of the animals and to evaluate the antioxidant properties of the aqueous extract of hulls of $C$. laurifolia (Acapurana $50 \mathrm{mg} / \mathrm{kg}$ ). In the same experimental model, Hartmann et al. showed the antioxidant and anti-inflammatory effects when using Boswellia serrata, which were also reported by Moura et al., with the use of mesalazine, and by Collares et al. with soy lecithin. ${ }^{19-21}$

The internal anal sphincter is composed of smooth muscles, and the significant increase in NO production can cause relaxation, which reduces sphincter anal pressure. Studies show that in AA-induced colitis there is a significant relaxation in sphincter anal pressure, measured in animals with colitis both at 24 and 48 hours. The results obtained in our research for the AA colitis induction group are in agreement with these data from the literature. And yet, in animals with induced colitis that received treatment with aqueous extract of hulls of $C$. laurifolia, a reversal of this effect can be observed, increasing the sphincter anal pressure in a similar way to the studies that administered antioxidant agents after induction of colitis. The possible increase in anal pressure in the colitis group treated with the aqueous extract of $C$. laurifolia may be associated with the presence of tannins. In the study with Hamamelis virginiana, rich in tannins, they were associated as the bioactive principle that reduced the inflammatory process by inducing local vasoconstriction in patients with hemorrhoids, which may corroborate this hipothesis. ${ }^{4,19-22}$

After induction of colitis, destruction of the crypts, of the edema of the submucosa and of the inflammatory infiltrate were observed. The histological evaluation shows an improvement in the intestinal tissue of animals with induced colitis and treated with the aqueous extract of $C$. laurifolia ( -Fig. 1D). This alteration seems to be linked to its antioxidant potential, as it presents protection to the intestinal mucosa with preservation of the crypts and reduction of edema in a similar way to what was observed in research using glutamine as an antioxidant, in experimental models of induced colitis. ${ }^{23,24}$

Since there are no phytochemical data in the literature with C. laurifolia, we based our study on the work of Rodrigues et al., who analyzed the hulls of $C$. comosa and observed the presence of flavonoids and tannins. Likewise, the study by Flores et al. showed a positive result for the presence of flavonoids, saponins, and tannins in the hulls of C. angustifolia. ${ }^{25,26}$

When analyzing studies with other plants of the same family of C. laurifolia, it was possible to observe similar results in the evaluation of the phytochemical profile with Hymenaea courbaril (Fabaceae) which showed high levels of phenolics, tannins, and total flavonoids of $516.89 \pm 2.63 \mathrm{mg} / \mathrm{g} \mathrm{GAE}$, $231.79 \pm 1.94 \mathrm{mg} / \mathrm{g}$ GAE, $3.90 \pm 0.05 \mathrm{mg} / \mathrm{g} \mathrm{QE}$, respectively, as well as a high antioxidant potential compared with DPPH of $\mathrm{IC}_{50}=33.97 \pm 0.55 \mu \mathrm{g} / \mathrm{ml}$, only 1.9 times less antioxidant than the quercetin standard. These data reinforce that the high levels of phenolic compounds are linked to high antioxidant activity. Still, Pereira et al., when analyzing the antioxidant potential against the DPPH of Myroxylon peruiferum (Fabaceae) bark, found a greater antioxidant activity (IC50 $=0.056 \pm 1.09 \mathrm{mg} / \mathrm{ml}$ ) than the positive quercetin control of $10.25 \pm 1.45 \mathrm{mg} / \mathrm{ml}$. Among the natural compounds found in vegetable origin extracts, there are saponins, flavonoids, and tannins that can act in the elimination of oxygenderived FRs. It is observed that they are present in C. laurifolia, and for that reason, they can be effective in different properties, including in the balance of OS due to its potent antioxidants. Our data show a high tannin content, and this secondary metabolite may be related to antioxidant activity, as they capture the FRs that intercept the active oxygen forming stable radicals and, therefore, the tannins inhibit LPO. Tannins also help to reduce the inflammatory process through the formation of a protective layer on the damaged skin or mucosa, with processes of epithelial restructuring and vessel formation. ${ }^{27-31}$

Colitis is related to oxidative damage by increasing FRs of oxygen and nitrogen that cause cell destruction, inflammatory infiltrate and the release of mediators, such as cytokines, potentiating stress. The oxygen FRs induce the LPO process, which is a chain reaction, acting on the membrane lipids with an initiation, propagation, and termination phase. In the present study, with the administration of $C$. laurifolia, we noticed a significant decrease in LPO when compared with animals of the CL group. This finding indicates an antioxidant power that may reduce the FRs, suggesting a scavenger activity accompanied by a reorganization of the intestinal mucosa, similarly to other studies in our group, using $B$. serrata, mesalazine, or soy lecithin. The reduction in LPO in the $\mathrm{CL}+\mathrm{A} 50$ group may be associated with the high concentration of tannins present in C. laurifolia, which assist in the interception of active oxygen and in the repair of FRs. ${ }^{6,19-21}$

The significant increase in SOD activity is in line with other research, which also used AA to induce colitis. The increased SOD activity is linked to the attempt to dismutate the superoxide anions and, thus, minimize the damage caused by AA. After using C. laurifolia, the $\mathrm{CL}+\mathrm{A} 50$ animals showed a significant reduction in SOD activity, approaching the control animals, which can be attributed to the presence of phenolic compounds in the aqueous extract of $C$. laurifolia. Glutathione is an important antioxidant and key in protecting against damage and deactivating FRs in the physiological system. In the present work, we observed a significant increase in the $\mathrm{CL}+\mathrm{A} 50$ group, results similar to those of Hartmann et al. with the use of B. serrata in colitis groups with antioxidants. The levels of GSH present in our research follow the literature, and it is also possible to observe in both studies the reestablishment of the activity of GSH levels in the groups with induced colitis that received antioxidant treatment, showing a restructuring of the intestine. Studies using menthol and methanolic extract of Calotropis procera also showed a decrease in GSH levels in groups with AA induced colitis and corroborate with the findings of our research. ${ }^{4,19-21,32-34}$ 


\section{Conclusion}

The aqueous extract of hulls of $C$. laurifolia showed antioxidant activity both in vitro and in vivo, by the treatment in the experimental model of colitis induced by AA. This effect is attributed to the presence of high concentrations of phenolic compounds with antioxidant potential. There was a restoration of intestinal architecture, increased sphincter anal pressure, reduced LPO damage, and reestablishment of SOD and GSH activities. The results were promising in the face of cases of colitis; however, we emphasize the need for further studies to assess the mechanism of action of the aqueous extract of hulls $C$. laurifolia in inflammatory pathways, the involvement of NO to evaluate its use in humans, in addition to the assessment of its toxicity in vivo.

\section{Sources of Support \\ CAPES; CNPq; FIPE-HCPA}

\section{Conflict of Interests}

The authors have no conflict of interests to declare.

\section{References}

1 Cambuy YRS, Natali MRM. Inflammatory bowel disease: narrative literature review. Rev Fac Ciên Méd Soroc. 2015; 17:116-119

2 Yoshino T, Sono M, Yazumi S. Usefulness of sulfasalazine for patients with refractoryulcerative colits. BMJ Open Gastroenterol 2016;3:1-7

3 Houli J, Netto GM. Retocolite ulcerativa inespecífica. Rev Bras Coloproctol 1984;4:191-205

4 Fillmann HS, Kretzmann N, Llesuy S, Fillmann LS, Marroni NP. O Papel do Óxido Nítrico na Pressão Anal Esfincteriana de Ratos Submetidos à Colite Experimental. Rev Bras Coloproctol 2006; 26:437-429

5 Halliwell B, Gutterridge JMC. Free radicals in Biology and Medicine. 4th. Oxford Uni Press; 2007:851

6 Chagas AP, Müller AH, Soares MBP, Garcez LM. Potencial anti- e imunomodulador dos extratos de Benth. (Fabaceae). Rev Inst Eva Cha. 2010;1:117-124

7 Falkenberg MB, Santos RI, Simões CMO. Introdução à análise fitoquímica. Ed UFRGS. 2007;5:23-288

8 Miliauskas G, Venskutonis PR, Van Beek TA. Screening of radical scavenging activity of some medicinal plants and aromatic plant extract. Food Chem 2004;85:231-237

9 Singleton VL, Rossi JA. Colorimetry of total phenolics with phosphomolybdic -phosphotungstic acid reagents. Americ Jour of Enolo and Viticult. 1965;16:144-158

10 Woiski R, Salatino A. Analysis of propolis: some parameters and procedures for chemical quality control. Jour of Apicult Resea. 1998;37:99-105

11 Mensor LL, Menezes FS, Leitão GG, et al. Screening of Brazilian plant extracts for antioxidant activity by the use of DPPH free radical method. Phytother Res 2001;15(02):127-130

12 E.E.C. Directive 2010/63/EU of the European Parliament and of the Council of 22 september 2010 on the protection of animals used for scientific purposes. Off J Eur Commun 2010; L276:33-77

13 Yamada Y, Post SR, Wang K, Tager HS, Bell GI, Seino S. Cloning and functional characterization of a family of human and mouse somatostatin receptors expressed in brain, gastrointestinal tract, and kidney. Proc Natl Acad Sci U S A 1992;89(01):251-255
14 Llesuy SF, Milei J, Molina H, Boveris A, Milei S. Comparison of lipid peroxidation and myocardial damage induced by adriamycin and 4'-epiadriamycin in mice. Tumori 1985;71(03):241-249

15 Bradford MM. A rapid and sensitive method for the quantitation of microgram quantities of protein utilizing the principle of protein-dye binding. Anal Biochem 1976;72:248-254

16 Buege JA, Aust SD. Microsomal lipid peroxidation. Methods Enzymol 1978;52:302-310

17 Misra HP, Fridovich I. The role of superoxide anion in the autoxidation of epinephrine and a simple assay for superoxide dismutase. J Biol Chem 1972;247(10):3170-3175

18 Beutler E, Duron O, Kelly BM. Improved method for the determination of blood glutathione. J Lab Clin Med 1963;61:882-888

19 Hartmann RM, Morgan Martins MI, Tieppo J, Fillmann HS, Marroni NP. Effect of Boswellia serrata on antioxidant status in an experimental model of colitis rats induced by acetic acid. Dig Dis Sci 2012;57(08):2038-2044

20 Moura RM, Hartmann RM, Licks F, et al. Antioxidant effect os mesalazine in the experimental colits model induced by acetic acid. J Coloproctol (Rio J) 2016;36:139-148

21 Colares JR, Schemitt EG, Hartmann RM, et al. Effect of lecithin on oxidative stress in an experimental model of rats colitis induced by acetic acid. J Coloproctol (Rio J) 2016;36:97-103

22 European Medicines Agency (EMEA) Hamamelidis folium et cortex aut ramunculus destillatum. Eur Un Herb Monograph 2010

23 Fillmann H, Kretzmann NA, San-Miguel B, et al. Glutamine inhibits over-expression of pro-inflammatory genes and downregulates the nuclear factor kappaB pathway in an experimental model of colitis in the rat. Toxicology 2007;236(03):217-226

24 Kretzmann NA, Fillmann H, Mauriz JL, et al. Effects of glutamine on proinflammatory gene expression and activation of nuclear factor kappa B and signal transducers and activators of transcription in TNBS-induced colitis. Inflamm Bowel Dis 2008;14(11):1504-1513

25 Rodrigues E, Duarte-Almeida JM, Pires JM. Perfil farmacológico e fitoquímico de plantas indicadas pelos caboclos do Parque Nacional do Jaú (AM) como potenciais analgésicas: parte I. Rev Bras Farmacogn 2010;20:981-991

26 Flores PC, Andoa DH. Características Farmacognósticas de Campsiandra angustifólia (huacapurana) de uso terapéutico tradicional en la ciudad de Iquitos 2013. Univ Naci de la Amaz Per 2014

27 Vencato SB, Lemes MLB, Campelo DS, Correa DS, Ferraz ABF. Avaliação do perfil fitoquímico e potencial antioxidante do extrato aquoso de Hymenaea courbaril. Ver Inic Cient Ulbra. 2016;14:55-66

28 Pereira R, Nascimento MF, Maciel DR, et al. Abordagem fitoquímica do extrato etanólico da casca de Myroxylon peruiferum L.f. Rev Vale Rio Verde. 2018;16:1-7

29 Awaad AS, El-Meligy RM, Soliman GA. Natural products in treatment of ulcerative colitis and peptic ulcer. J Sau Chem. Soci. 2013; 17:101-124

30 Vinha AF, Soares MO, Castro A, Santos A, Oliveira MBPP, Machado $M$. Phytochemical characterization and radical scavenging activity of aqueous extracts of medicinal plants from Portugal. European J Med Plants 2012;2:335-347

31 Santos SC, Mello JCP. Taninos. Edit. Univ. Fed. Rio Gran. Sul. 2007; $5: 23-288$

32 Shan XQ Aw TY, Jones DP. Glutatione-dependent protection against oxidative injury. Aliment Pharmacol Ther 1991;47:61-71

33 Bastaki SMA, Adeghate E, Amir N, Ojha S, Oz M. Menthol inhibits oxidative stress and inflammation in acetic acid-induced colitis in rat colonic mucosa. Am J Transl Res 2018;10(12):4210-4222

34 Kumar VL, Pandey A, Verma S, Das P. Protection afforded by methanol extract of Calotropis procera latex in experimental model of colitis is mediated through inhibition of oxidative stress and pro-inflammatory signaling. Biomed Pharmacother 2019; 109:1602-1609 